\title{
A lesson in urban mycology: Critically Endangered polypore Trametes suaveolens (Basidiomycota) re-discovered in Estonia
}

\author{
Kadri Runnel ${ }^{1}$, Sulev Järve ${ }^{2} \&$ Asko Lóhmus $^{1^{*}}$ \\ ${ }^{1}$ Institute of Ecology and Earth Sciences, University of Tartu, Vanemuise 46, 51014 Tartu \\ ${ }^{2}$ Tallinn Environment Department, Harju 13, 10130 Tallinn \\ *corresponding author: asko.lohmus@ut.ee
}

\begin{abstract}
The conspicuous, mostly willow-inhabiting polypore Trametes suaveolens is a threatened species in Northern Europe. In Estonia it is listed as Critically Endangered, and has not been found since 1984. We report an apparently viable population discovered in Central Tallinn, inhabiting old Salix fragilis and S. alba trees and stumps along ca. $1.5 \mathrm{~km}$ of the Baltic seashore. The host trees are prone to removal due to city development and park care reasons. We discuss potential conservation measures for sustaining this unique population in the urban conditions.
\end{abstract}

Kokkuvóte: Pajutagel (Trametes suaveolens) Eestis taasleitud Peamiselt remmelgatel silmatorkavaid viljakehi moodustav pajutagel (Trametes suaveolens) on Póhja-Euroopas ohustatud liik. Eestis on selle liigi seisund hinnatud kriitiliseks ja viimane dokumenteeritud leid pärineb 1984. aastast. Siinses artiklis kirjeldatakse Tallinnast avastatud populatsiooni, mis asustab u. $1,5 \mathrm{~km}$ mereärörel lôigul rabeda remmelga (Salix fragilis) ja hôberemmelga (S. alba) vanu elus puid ja kände. See asurkond oli 2018. aastal küll elujōuline, kuid tema elupaika ohustavad linna arendustegevus ja pargihooldus. Artiklis esitatakse soovitusi nii pajutagla säilitamiseks Tallinnas kui ka üldiselt puitulagundavate ohustatud seeneliikide kaitseks linnatingimustes.

Keywords: arboriculture, conservation, red-listed species, wood-decaying fungi, urban green space

\section{INTRODUCTION}

At least since the 1990s, wood-decaying fungi have been at the forefront of fungal conservation, with the main focus on old-growth forest habitats (Parmasto, 2001; Junninen \& Komonen, 2011) However, several threatened species of wood-decaying fungi inhabit semi-open habitats, including solitary trees in riverine and agricultural areas, wooded meadows and, recently, urban green space (parks, cemeteries, etc.). In northern Europe, such a species is the polypore Trametes suaveolens (L.) Fr., (Agaricomycetes, Polyporales, Polyporaceae). This pileate species with annual, cream-colored fruit bodies (Fig. 1) and a pleasant anise odor inhabits mostly old willow trees (Salix spp.), often in riverine conditions (Zmitrovich, 2016). In Sweden, its population comprises ca. 75 locations and is declining due to the loss of semi-natural habitats (Artdatabanken, 2015); in Finland it has persisted mostly in parks (Niemelä, 2016). T. suaveolens is at the northern edge of its distribution range in Fennoscandia. The species is distributed throughout the temperate zone in Europe and is less rare in central-southern Europe (Bernicchia, 2005). It is also known from North-America, Asian Russia and Japan (Ryvarden \& Gilbertson, 1994; GBIF, 2018).

In Estonia, Trametes suaveolens has not been reported since 1984. There are a total of 13 historical records from the eastern and southern parts of the country, including three urban populations (Parmasto, 2004; http://elurikkus. ut.ee). In the current paper, we report on the discovery of an apparently viable population in Tallinn, northern Estonia. We describe the ecology and conservation challenges of this urban population, which provides insights into the general issue of conserving wood-inhabiting fungi in urban green space.

\section{MATERIALS AND METHODS}

Polypores in Estonia, including the territory of Tallinn City, have been relatively well surveyed since the 1950s (Parmasto, 2004). However, the first collection of $\mathrm{T}$. suaveolens in Tallinn was only made on 5 January 2018 by the author S.J., during arborist work in a Central Tallinn park. In March 2018 all potential habitats in 


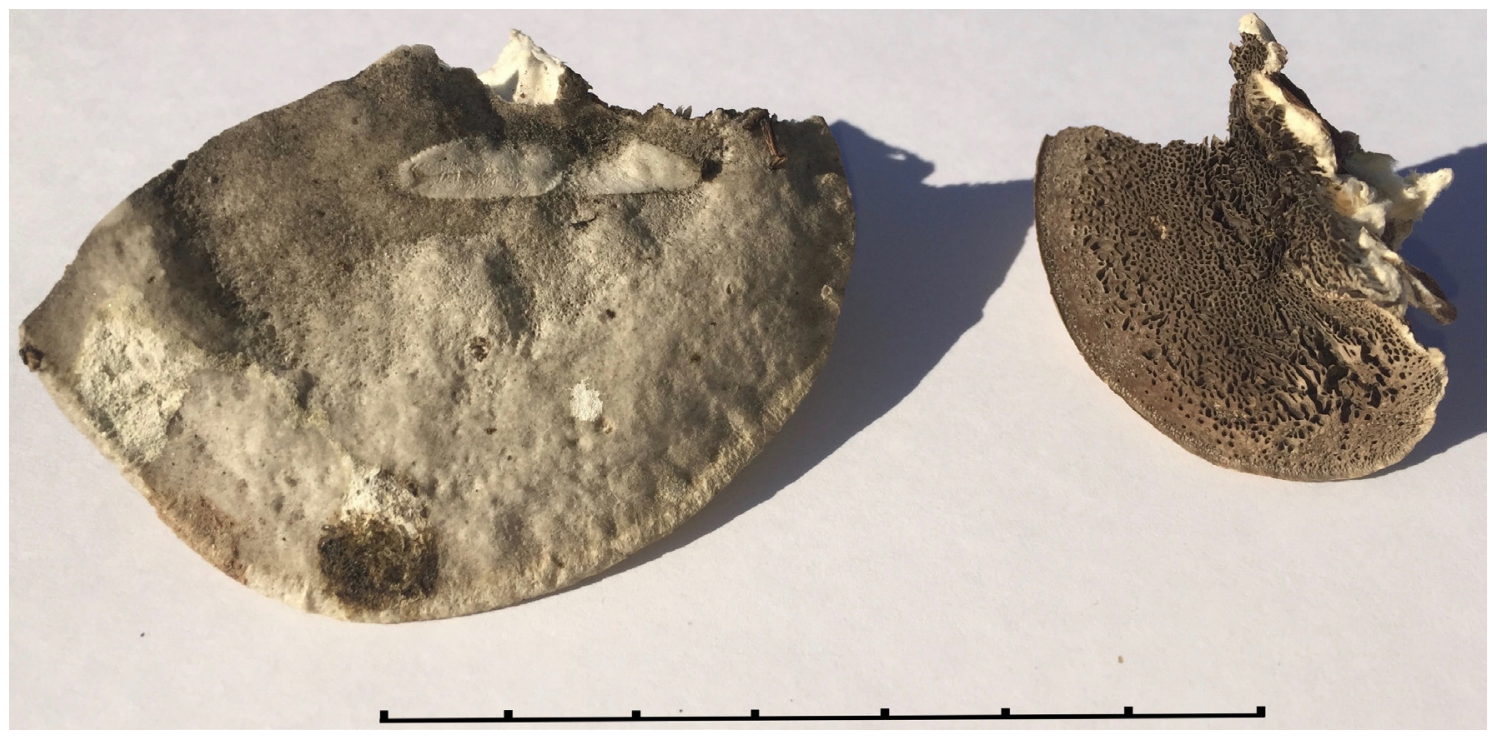

Fig. 1. Dried fruit bodies of Trametes suaveolens (TU 128008 and TU 128010). The scale bar units are $\mathrm{cm}$.

the surroundings were thoroughly checked by the authors, the locations and substrates found were mapped and described. We also critically reviewed earlier field notes by S.J. regarding the same trees (fruit bodies likely to represent T. suaveolens but no material collected), which provided some retrospective of the population history.

The species is easy to recognize in the field, but voucher specimens from 2018 were nevertheless collected and stored in fungaria of the University of Tartu (TU 128008; TU 128010) and of the Tallinn Botanic Garden (TALL F003300).

\section{RESULTS}

In total, we registered three locations in Central Tallinn, which were situated along ca. $1.5 \mathrm{~km}$ of the seashore (100-350 $\mathrm{m}$ from the shore). Earlier field notes from two locations indicated the existence of a viable population at least since 2013. In 2018, only one substrate of the sixteen recorded appeared safe from city development.

Location 1 (350 $\mathrm{m}$ from the seacoast) was a core population where fruit bodies were found on twelve old stumps of Salix fragilis. Seven stumps were of single stems $70-90 \mathrm{~cm}$ in diameter (Fig. $2 \mathrm{a})$; the rest were smaller stumps of multiple stems. This location had been a small remnant wood with ca. 100 trees (about 30 Salix spp.) that were felled in 2013 for road development; at the inspection preceding the felling, S.J. had observed white fruit bodies of presumably $T$. suaveolens on 1-2 trees. All the stumps were to be removed during the spring 2018. In March 2018, the oldest fruit bodies were $2-3$ years old, while most were from 2017; in total, six stumps had $>10$ fruit bodies (one had $>50$ ). Other polypore species observed on the same stumps included Bjerkandera adusta, Fomitopsis pinicola, Phellinus igniarius and Trametes versicolor. Three live $S$. fragilis trees grew within $100 \mathrm{~m}$ but no fruit bodies of $T$. suaveolens were found there.

Location 2 was situated 130 m east from Location 1, on a viable old Salix fragilis tree (diameter at breast height, DBH $91 \mathrm{~cm}$; age $>50$ years) at the street. The tree had been pruned for safety reasons in 2013. Around two large pruning scars, there were $>30$ fruit bodies from at least two previous fruiting seasons, between 1-2.5 m height (Fig. 2b); the tree also had fruit bodies of $P$. igniarius. There were no similar $S$. fragilis trees within $100 \mathrm{~m}$.

Location 3 was situated $1.5 \mathrm{~km}$ east from Location 1 , in a historical city park. In 2013, S.J. had noted fruit bodies of $T$. suaveolens on two 


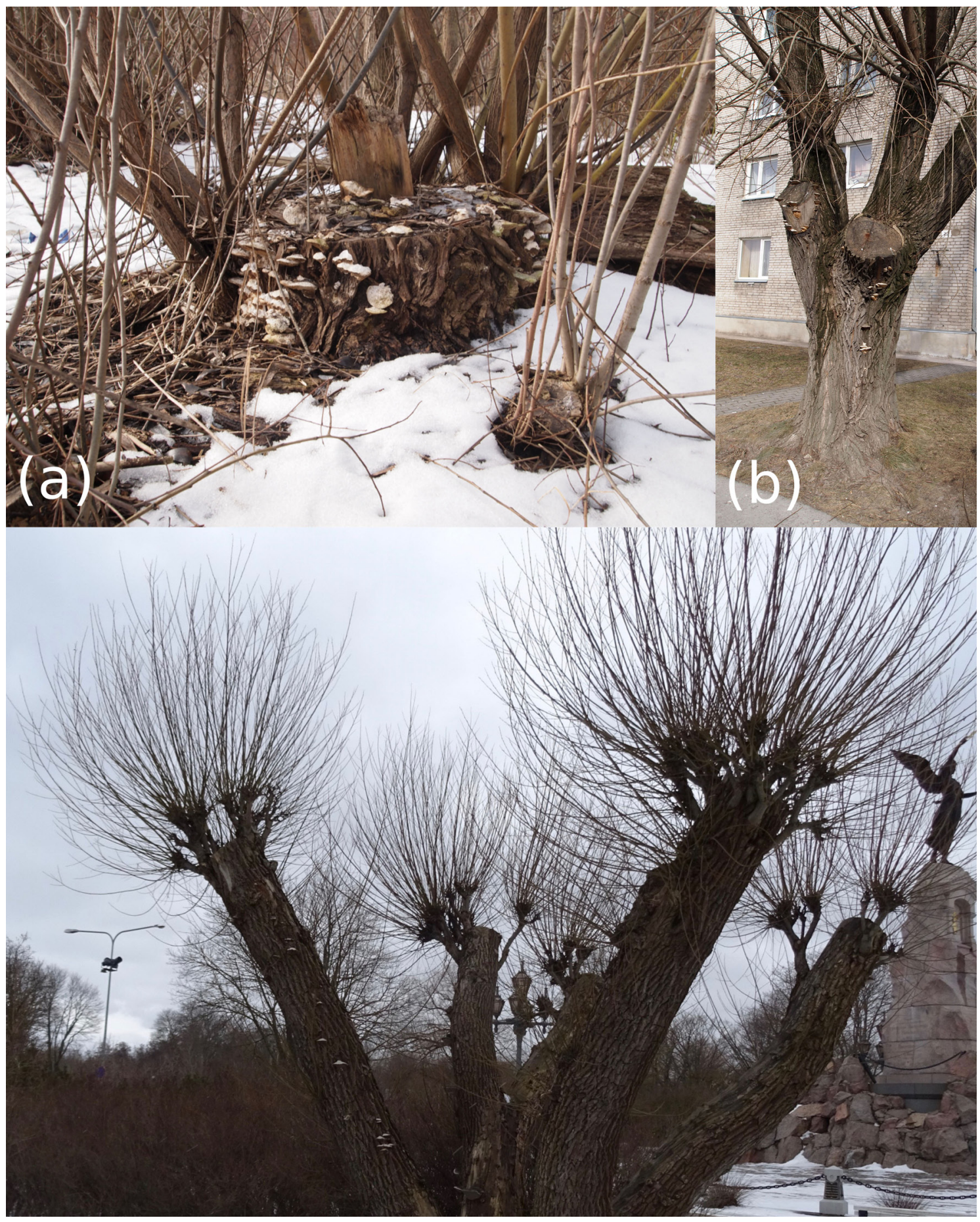

Fig. 2. Habitats of Trametes suaveolens on Salix fragilis in three locations in Central Tallinn: an occupied stump in Location 1 (a) and pruned trees in Location 2 (b) and 3 (c). Photo courtesy: A. Lõhmus (a,b) and S. Järve (c), March 2018. 
adjacent live Salix alba trees. In March 2018, both of these trees were marked for felling (road development); one tree (DBH $70 \mathrm{~cm}$ ) still had the fruit bodies in a pruning scar, while the scar on the second tree (DBH $55 \mathrm{~cm}$ ) had compartmentalized and had no fruit bodies. In addition, ca 15 fruit bodies were found on a multiple-stem pruned old Salix fragilis tree, $120 \mathrm{~m}$ apart (Fig. 2c). All the stems had heart rot of $P$. igniarius, and S.J. estimated the possibilities to preserve this tree for maximum 10 years in such park setting. The fruit bodies of $T$. suaveolens were found at 0.5-3 $\mathrm{m}$ height on one stem (DBH 49 $\mathrm{cm}$, age at least 50 years). There were two other similar S. fragilis trees within $100 \mathrm{~m}$.

\section{DISCUSSION}

Despite a lack of observations during the past 30 years, Trametes suaveolens appeared to be not regionally extinct in Estonia. Based on the IUCN red-listing criteria (IUCN, 2012), we have recently assessed this species as Critically Endangered and, to enable site protection when found, we suggested attributing it legal protection (category II; Lõhmus et al., 2018). The discovery of an apparently viable population of $T$. suaveolens in Tallinn, which is obviously threatened by the city development, supports these considerations. Our records of old fruit bodies in 2018 and earlier field notes indicate that this population has inhabited Tallinn for at least a decade. Yet it has remained undetected - despite conspicuous fruit bodies, host trees in public places, and frequent visiting of the city by mycologists.

The records from Tallinn clarified some aspects of the ecology of $T$. suaveolens. First, the fruit bodies were mostly found on Salix fragilis, despite frequent occurrence of other willow species (S. alba, S. caprea) in the same sites. Such preference is in line with the recent observations by Zmitrovich (2016) in the St. Petersburg region, although it contrasts with the historical Estonian records where $S$. alba has been listed most frequently and S. fragilis not at all (Parmasto, 2004). A possible explanation for such discrepancy is that $S$. fragilis may be a less known species and less frequently used as an ornamental tree in human settlements where the former casual collections mostly originate. Thus, our observations suggest (see also Zmitrovich, 2016) that a primary habitat of $T$. suaveolens in the Baltic region are old single $S$. fragilis trees on riverbanks and riverine deciduous forests. Such habitats are hitherto poorly studied in Estonia, and should be given a survey priority. In addition to $T$. suaveolens, riverine areas may be crucial for several other threatened and insufficiently surveyed polypores in Estonia (e.g. Antrodia mellita, A. pulvinascens, Tyromyces fumidiceps; Lõhmus et al., 2018).

Secondly, all the fruit bodies were found on pruned old trees or tree stumps. Hence, for sustaining the urban populations of $T$. suaveolens retaining old $S$. fragilis trees should be given special attention but there is no reason to restrict pruning (rather the contrary). Our observations reveal that the first fruit bodies appear about three years after cutting large branches or felling the trees (on stumps); it suggests that the species colonizes recently cut dead-wood surfaces. Thus, if it is necessary to fell an occupied tree (e.g. for safety reasons), we recommend retaining a high stump. Such management techniques could also benefit some other threatened polypore species with similar ecology (e.g., Trametes gibbosa) and have a wider biodiversity effect for other saproxylic taxa, such as beetles (Lindhe et al., 2004).

Finally, the spatial distribution of our records indicates that $T$. suaveolens can successfully disperse at least a few hundreds of meters, which implies how its populations could be managed for substrate availability. Such considerations are particularly important in the city conditions where long-term planning of high vegetation is complex. Thus, threatened wood-inhabiting fungi represent an interesting case for urban planners, and such arboricultural issues will expectably gain importance for biodiversity conservation in the urbanizing world.

\section{ACKNOWLEDGEMENTS}

We thank Kadri Pärtel, Ivan Zmitrovich and an anonymous reviewer for constructive comments on the manuscript. Financial support to A.L. and K.R. was provided by the Estonian Research Council (grant IUT 34-7). 


\section{REFERENCES}

ArtDatabanken, 2015. Rödlistade arter i Sverige 2015. ArtDatabanken SLU, Uppsala.

Bernicchia, A., 2005 Fungi Europei: Polyporaceae s.l. Candusso, Alassio SV, pp. 1-808.

eElurikkus (Database of Estonian Biodiversity). http: / / elurikkus.ut.ee

GBIF (Global Biodiversity Information Database). https://www.gbif.org

IUCN, 2012. IUCN Red List Categories and Criteria: Version 3.1. Second edition. Gland, Switzerland and Cambridge.

Junninen, K. \& Komonen, A. 2011. Conservation ecology of boreal polypores: a review. Biological Conservation 144: 11-20. https://doi.org/10.1016/j. biocon.2010.07.010

Lindhe, A., Åsenblad, N. \& Toresson, H. G. 2004. Cut logs and high stumps of spruce, birch, aspen and oak-nine years of saproxylic fungi succession. Biological Conservation 119: 443-454. https:// doi.org/10.1016/j.biocon.2004.01.005
Lõhmus, A., Vunk, E. \& Runnel, K. 2018. Conservation management for forest fungi in Estonia: the case of polypores. Folia Cryptogamica Estonica 55: 79-89. https:/ / doi.org/10.12697/fce.2018.55.08

Niemelä, T. 2016. Suomen käävät. Norrlinia 31: 1-432.

Parmasto, E. 2001. Fungi as indicators of primeval and old-growth forests deserving protection. In: Moore, D. et al. (eds.) Fungal Conservation. Issues and Solutions. Cambridge University Press, Cambridge, pp. 81-88. https://doi.org/10.1017/ CBO9780511565168.006

Parmasto, E. 2004. Distribution Maps of Estonian Fungi. III. Pore Fungi. Institute of Zoology and Botany of the Estonian Agricultural University, Tartu.

Ryvarden, L. \& Gilbertson, R. 1994. European Polypores. Synopsis fungorum 6, 7: 1-743.

Zmitrovich, I.V. 2016. Noteworthy polypores of Pushkin city near the Saint Petersburg (Russia), the reserve of old-growth trees. 1. Trametes suaveolens. Agriculture and Forestry 62: 81-90. https: / / doi.org/ 10.17707/AgricultForest.62.2.06 
96 Folia Cryptog. Estonica 